Before Harlem 
POLITICS AND CULTURE IN MODERN AMERICA Series Editors: Glenda Gilmore, Michael Kazin, Thomas J. Sugrue

Volumes in the series narrate and analyze political and social change in the broadest dimensions from 1865 to the present, including ideas about the ways people have sought and wielded power in the public sphere and the language and institutions of politics at all levelsnational, regional, and local. The series is motivated by a desire to reverse the fragmentation of modern U.S. history and to encourage synthetic perspectives on social movements and the state, on gender, race, and labor, on consumption, and on intellectual history and popular culture. 


\title{
Before Harlem
}

The Black Experience in New York City Before World War I

\author{
MARCY S. SACKS
}

\section{$\overline{\text { PENN }}$}

University of Pennsylvania Press

Philadelphia 
Copyright $(2006$ University of Pennsylvania Press

All rights reserved

Printed in the United States of America on acid-free paper

$\begin{array}{llllllllll}10 & 9 & 8 & 7 & 6 & 5 & 4 & 3 & 2 & 1\end{array}$

Published by

University of Pennsylvania Press

Philadelphia, Pennsylvania 19104-4112

A Cataloging-in-Publication record is available from the Library of Congress

ISBN-13: 978-0-8122-3961-4

ISBN-10: 0-8122-3961-X 
A Rodolfo, para siempre

$y$

para Alejandro y Daniela, la esperanza del futuro 
